\title{
Ischemic Discomfort Indicator
}

National Cancer Institute

\section{Source}

National Cancer Institute. Ischemic Discomfort Indicator. NCI Thesaurus. Code C119235.

An indication as to whether the subject has symptoms of ischemic discomfort. 